\title{
Influence of bullying and teacher-student relationship on school engagement: Analysis of an explanatory model
}

\section{Influência do "bullying" e da relação professor-aluno no engajamento escolar: análise de um modelo explicativo}

\author{
Jessica Elena VALLE ${ }^{1}$ (D) 0000-0002-3241-6911 \\ Ana Carina STELKO-PEREIRA ${ }^{2}$ ID 0000-0002-8089-132X \\ Evandro Morais PEIXOTO3 ID 0000-0003-1007-3433 \\ Lucia Cavalcanti de Albuquerque WILLIAMS ${ }^{1}$ (iD) 0000-0003-3425-6656
}

\begin{abstract}
The present study investigated the influence of bullying involvement and teacher-student relationship on school engagement, through the analysis of an explanatory model. For this, 426 students (from $6^{\text {th }}$ to $9^{\text {th }}$ grades) from four public schools located in a city in the state of São Paulo, Brazil, answered the Escala de Violência Escolar - Versão Estudante (School Violence Scale - Student Version), the Escala de Relação Professor-Aluno (Teacher - Student Relationship Scale) and the School Engagement Scale. Results from a Path Analysis indicated that bullying involvement has a direct negative impact on school engagement, and that teacher-student relationship has a direct positive impact on school engagement. Moreover, teacher-student relationship may mediate the negative effects of bullying on school engagement. These data confirm the importance of positive social relationships in school for student engagement. However, the proposed model explains $32 \%$ of the variance of school engagement, indicating that other variables not investigated in this study may also be relevant.
\end{abstract}

Keywords: Bullying; Interpersonal relations; Involvement.

1 Universidade Federal de São Carlos, Centro de Educação e Ciências Humanas, Programa de Pós-Graduação em Psicologia. Rodovia Washington Luís, s/n., km 235, 13565-905, São Carlos, SP, Brasil. Correspondência para/Correspondence to: J.E. VALLE. E-mail: <jeh.valle92@gmail.com>.

2 Universidade Estadual do Ceará, Centro de Ciências da Saúde, Programa de Pós-Graduação em Saúde Coletiva. Fortaleza, CE, Brasil.

3 Universidade de Pernambuco, Curso de Psicologia, Departamento de Psicologia. Recife, PE, Brasil.

Article based on the master's thesis of J.E. VALLE, entitled "The influence of bullying involvement and teacher-student relationship on school engagement". Universidade Federal de São Carlos, 2017.

Support: Conselho Nacional de Desenvolvimento Científico e Tecnológico (Process no 132770/2015-6),

$\mathbf{v} \mathbf{v} \mathbf{v}$

Como citar este artigo/How to cite this article

Valle, J. E., Stelko-Pereira, A. C., Peixoto, E. M., \& Williams, L. C. A. (2018).Influence of bullying and teacher-student relationship on school engagement: Analysis of an explanatory model. Estudos de Psicologia (Campinas), 35(4), 411-420. http://dx.doi.org/10.1590/19 82-02752018000400008 


\section{Resumo}

O presente estudo investigou a influência do envolvimento em "bullying" e da relação professor-aluno no engajamento escolar. Para isso, 426 alunos de $6^{\circ}$ a $9^{\circ}$ ano do Ensino Fundamental, de quatro escolas públicas do interior do estado de São Paulo, responderam a três instrumentos: Escala de Violência Escolar - Versão Estudante, Escala de Relação Professor-Aluno e School Engagement Scale (Escala de Engajamento Escolar). Foi realizada Análise de Trajetórias e notou-se que o envolvimento em "bullying" tem impacto negativo direto no engajamento escolar, ao passo que a relação professor-aluno tem impacto positivo direto nessa esfera. Adicionalmente, a relação professor-aluno pode mediar os efeitos negativos da autoria e da vitimização por "bullying" no engajamento escolar. Esses dados confirmam a importância de relacionamentos sociais positivos na escola para o engajamento dos alunos. Contudo, o modelo proposto explica 32\% da variância do engajamento escolar, indicando que outras variáveis não investigadas também podem ser relevantes.

Palavras-chave: Bullying; Relações interpessoais; Envolvimento.

Since the very beginning of their school lives, students are confronted with challenges, such as having to adapt to a group social setting, and meet school demands (Archambault, Pagani, \& Fitzpatrick, 2013). In this context, school engagement is relevant because it refers to the relation of students to their school experiences (Fredricks, Blumenfeld, \& Paris, 2004) and it is a predictor of academic success as well as an indicator of the quality of interpersonal relationships (Fredricks et al., 2004; Li \& Lerner, 2013; Organisation for Economic Co-operation and Development [OECD], 2013). Such a multi-layered construct is composed of three inter-related dimensions: 1) emotional students' affective reactions towards the school, involving feelings, attitudes, and perceptions concerning the school environment and its members; 2) behavioral - observable actions, such as participation in activities and following the rules; and 3) cognitive - motivation, interest, and effort in learning (Fredricks et al., 2004).

In a study concerning school engagement carried out in 65 different countries, 18\% of students reported intentionally skipping classes, $19 \%$ claimed not feeling a sense of belonging at school, and $12 \%$ thought of school as a waste of time, indicating that a considerable number of students are disengaged in the educational process (OECD, 2013). Lack of school engagement is a concern because disengaged students are more likely to present academic failure, school evasion, and behavioral problems (Fredricks et al., 2004). Because of this, interest in studying school engagement has been on the rise, through the examination of possible contributing factors, especially those related to the school environment, with an emphasis on student interpersonal relationships with their peers as well as with their teachers.

In interactions amongst peers, bullying is a relevant factor occurring when one or more students employ repetitive, intentional, aggressive behavior over a prolonged period of time against another student or group of students (Olweus, 1993). In such situations, these students may be involved as victims, perpetrators, victim-perpetrators, or bystanders (Berger, 2007; Orpinas \& Horne, 2006). Abuse may be physical, verbal, relational, or by means of electronic communication devices (cyberbullying) (Berger, 2007; Gladden, VivoloKantor, Hamburger, \& Lumpkin, 2014; Williams \& Stelko-Pereira, 2013).

In Brazil, studies show that bullying prevalence rates may vary from $7.2 \%$ to $48.5 \%$ for victims, from $7.1 \%$ to $31.6 \%$ for perpetrators, and from $2.5 \%$ to $27.0 \%$ for victim-perpetrators (Brito \& Oliveira, 2013; Malta et al., 2014; Rech, Halpern, Tedesco, \& Santos, 2013). However, regardless of the type of involvement, bullying may result in physical, emotional, social, and academic impairment (Albuquerque, Williams, \& D'Affonseca, 2013; Olweus, 1993; Orpinas \& Horne, 2006).

Within the academic context, bullying can generate a negative school environment, resulting in the impairment of students' school engagement and academic performance. In this regard, when a student perceives or is involved in bullying there may be a decline in the school engagement components, in other words, there is a decrease in their sense 
of belonging and affective reactions towards the school, in participating of school activities and following rules, and in motivation and interest in studying (lyer, Kochenderfer-Ladd, Eisenberg, \& Thompson, 2010; Mehta, Cornell, Fan, \& Gregory, 2013).

Furthermore, teacher-student relationships are shown to be an important aspect, involving components of support and conflict (Hamre, Pianta, Downer, \& Mashburn, 2008; Penrose, 2009). This relationship with teachers is of critical importance to the academic process, as it enables the connection between the student and the learning process (Penrose, 2009).

A number of studies indicate that the relationship with teachers influences the school engagement of students. In this regard, a positive teacher-student relationship contributes to school engagement in such a way that students tend to demonstrate a greater sense of belonging, participating in activities, following rules, and being motivated to learn. In contrast, a negative teacherstudent relationship impairs school engagement; students do not feel as if they belong, they avoid going to school, they tend not to work hard, and display a larger number of behavioral problems (Archambault et al., 2013; Portilla, Ballard, Adler, Boyce, \& Obradovic, 2014; Roorda, Koomen, Spilt, \& Oort, 2011).

Additionally, there is evidence supporting that teacher-student relationships and bullying involvement may bear concurrent influence over school engagement. Concerning this, a study carried out by Valle, Stelko-Pereira, Sá, and Williams (2015) investigated the influence of bullying victimization, bullying perpetration, and staff victimization over emotional school engagement. Participants were sourced from two different public schools in the state of São Paulo; a total of 634 students from $6^{\text {th }}$ to $9^{\text {th }}$ grades participated. Negative associations were found between bullying victimization or perpetration and emotional school engagement whereas positive associations were found between bullying perpetration and staff victimization.

The authors also proposed an explanatory model for emotional school engagement and the results indicated that bullying perpetration and staff victimization have a direct negative effect on emotional school engagement $(\beta=-0.14$ and $\beta=-0.03$, respectively), while bullying victimization has an indirect negative impact on the students' emotional school engagement due to bullying perpetration and staff victimization $(\beta=-0.07$ and $\beta=-0.002$, respectively). Therefore, the authors identified bullying victimization, bullying perpetration, and staff victimization as risk factors that deter emotional school engagement (Valle et al., 2015).

Continuing in this line of study, Cunha (2012) investigated how the quality of teacherstudent relationships could ease the relation between bullying aggression and victimization and the school engagement of students. A total of 691 students from $6^{\text {th }}$ to $9^{\text {th }}$ grades of a public school in the city of Curitiba, Brazil, participated in the study. The findings indicated that direct aggressions, relational aggressions, and victimization are negatively associated to student school engagement. Furthermore, positive aspects of teacher-student relationships are positively associated to school engagement, while negative aspects of teacher-student relationships are negatively associated to school engagement. Additionally, positive aspects of teacher-student relationships are negatively associated to aggression and victimization, while negative aspects of teacherstudent relationships are positively associated to aggression and victimization.

Analysis of the regression model conducted by Cunha (2012) indicated that aggression or victimization had no significant direct effects on school engagement. However, in regards to the teacher-student relationship, it was found that approval and instrumental support promote a positive effect on school engagement $(\beta=0.11$ and $\beta=0.08$, respectively; $p<0.01$ ), while conflict promotes a negative effect $(\beta=-0.09, p<0.01)$. Furthermore, part of the results indicated that the negative effects of bullying aggression or victimization on school engagement are mitigated by aspects pertaining to teacher-student relationships, where students who display a greater amount of positive aspects in their relationships with teachers tend to 
have the negative effects of bullying aggression or victimization mitigated. By contrast, students who display more negative aspects in their relationships with teachers tend to have the negative effects of bullying aggression or victimization on school engagement exacerbated.

In this regard, Cunha (2012) noted that, in the individual dimension, the interaction between relational aggression towards peers and conflict with teachers, as well as the interaction between peer victimization and exclusion perpetrated by the teachers bear negative effects on school engagement $(\beta=-0.11$ and $\beta=-0.07$, respectively; $p<0.05)$. Additionally, within the context of the class as a whole, the effects that direct aggression towards peers have over school engagement were moderated by students' closeness to teachers ( $\beta=0.45, p<0.01)$; the effects of relational aggression towards peers were moderated by exclusion from teachers $(\beta=-0.82, p<0.01)$; and the effects of peer victimization were moderated by conflicts with teachers $(\beta=-0.53, p<0.05)$.

Despite the results obtained by Cunha (2012) and Valle et al. (2015), there are only a few studies that simultaneously investigate bullying involvement, teacher-student relationships, and school engagement. Thus, this study investigated the simultaneous influence of bullying involvement, teacher-student relationships, and school engagement, through the analysis of an explanatory model. As a result, it would be possible to intervene in these variables, reducing risks and promoting a healthy environment that would allow for an increase in school engagement, improvement in learning, and better opportunities for students' academic and social success, as pointed out by the literature (Fredricks et al., 2004; Mehta et al., 2013).

\section{Method}

\section{Participants}

A total of 426 students from $6^{\text {th }}$ to $9^{\text {th }}$ grades from four different public schools of a city in the state of São Paulo participated in the study.
Participants had a mean age of 12.65 years $(S D=1.18)$, ranging from 10 to 17 years, of which $58.0 \%$ were females. With regards to specific school years, $26.1 \%$ were attending $6^{\text {th }}$ grade; $20.9 \% 7^{\text {th }}$ grade; $26.8 \% 8^{\text {th }}$ grade; and $26.3 \%$ the $9^{\text {th }}$ grade. Participating schools were located in lower middle class regions with social vulnerability rates considered low or very low, according to the Índice Paulista de Vulnerabilidade Social (IPVS, São Paulo State Index of Social Vulnerability), having been rated 2 and 3 (the index goes up to 7 , which corresponds to the highest vulnerability group) (Fundação do Sistema Estadual de Análise de Dados [SEAD], 2010).

\section{Instruments}

A compilation of instruments, detailed below, was employed for data collection. They were answered by participants considering the period of 30 days prior to data collection as reference.

Bullying involvement: This variable was measured using the Escala de Violência Escolar Versão Estudante (EVE, School Violence Scale Student Version), originally called Questionário de Investigação de Prevalência de Violência Escolar (QIPVE, Questionnaire for the Investigation of School Violence Prevalence) (Stelko-Pereira, Williams, \& Freitas, 2010), which investigates school violence as experienced and practiced by students. The instrument is filled out on a five-point Likert scale, ranging from 1 (never) to 5 (7 times or more). In this study a subscale of victimization of students by students was applied, encompassing 18 questions (e.g.: Has any student at your school: Destroyed your school material on purpose? Punched you?); and a subscale of perpetration of violence against students by students, encompassing 18 questions (e.g.: Have you ever done any of the following to another student at your school: Spread gossip? Punched him/her?).

In this study, adjustment indexes were considered adequate for both EVE subscales: for the victimization subscale, findings indicated $\mathrm{WLSMV} \chi^{2}=333.70, d f=134, p<0.001, \chi^{2} / d f=2.49$, 
$\mathrm{CFI}=0.945, \mathrm{TLI}=0.938$, and RMSEA $=0.059$ (I.C. $90 \%=0.051-0.067)$, while for the perpetration subscale findings indicated $\mathrm{WLSMV} \chi^{2}=261.772$, $d f=134, p<0.001, \chi^{2} / d f=1.95, C F I=0.971$, $\mathrm{TLI}=0.967$, and RMSEA $=0.047$ (I.C. $90 \%=$ 0.039 - 0.056). Moreover, Confirmatory Factor Analysis validated the factorial structure of the instrument. Cronbach's Alpha Coefficient indicated the following precision indexes: regarding the victimization subscale $\alpha=0.850$ for the presential factor; $\alpha=0.804$ virtual; and $\alpha=0.872$ total; and for the perpetration subscale: $\alpha=0.853$ for the presential factor; $\alpha=0.724$ virtual; and $\alpha=0.833$ total.

Relationship with teachers. This variable was measured using the Escala de Relação Professor-Aluno (ERPA, Teacher-Student Relationship Scale) (Lamas, Freitas, \& Barbosa, 2013) which identifies the student's perception in regard to his or her relationship with teachers. The scale is composed of 15 items on a five-point Likert scale, ranging from 1 (always) to 5 (never), with regards to adequate or dysfunctional relations with teachers. The instrument is organized around two factors: affinity (e.g.: I have a nice relationship with this teacher; I believe the relationship I have with this teacher is important); and conflict (e.g.: I do not trust this teacher; I argue or I do not get along with this teacher). Participants were supposed to evaluate the relationship they had with a specific teacher who was drawn at random for each class of students. Furthermore, a question was made in order to advance considerations regarding interactions with the other teachers [Your relationship with the other teachers is (consider all of the other teachers in general terms): much better, better, similar, worse, or much worse than what you have with this teacher?].

In this study, the adjustment indexes for the instrument were considered to be adequate: $\mathrm{WLSMV} \chi^{2}=401.142, d f=87, \chi^{2} / d f=4.61, \mathrm{CFI}=0.927$, $\mathrm{TLI}=0.912$, and RMSEA $=0.092$ (I.C. $90 \%=0.083$ - 0.101). Moreover, Confirmatory Factor Analysis validated the factorial structure of the instrument, with Cronbach's Alpha Coefficient indicating the following precision indexes: $\alpha=0.777$ for the affinity factor; $\alpha=0.809$ conflict; and $\alpha=0.823$ total.

School engagement: This variable was evaluated using the School Engagement Scale, by Fredricks, Blumenfeld, Friedel, and Paris (2005) in a partnership with MacArthur Network for Successful Pathways. The instrument consists of a set of scales assessing different types of school engagement with 19 items, on a five-point Likert scale, ranging from 1 (never) to 5 (always), encompassing the three factors of school engagement: behavioral (e.g.: I pay attention in class, I follow the rules at school); emotional (e.g.: I feel happy in school, I like being at school); and cognitive (e.g.: I study at home even when I don't have a test, I check my schoolwork for mistakes).

The instrument was translated from English to Portuguese by the first author, and the resulting version was proofread and corrected both by the second author and by the last author. In this study, the following adjustment indexes were considered to be adequate for the instrument: $\mathrm{WLSMV} \chi^{2}=518.593, d f=149, p<0.001, \chi^{2} / d f=3.48$, $\mathrm{CFI}=0.929, \mathrm{TLI}=0.919$, and RMSEA $=0.076$ (I.C. $90 \%=0.069-0.84)$. Moreover, Confirmatory Factor Analysis validated the factorial structure of the instrument, with Cronbach's Alpha Coefficient indicating these precision indexes: $\alpha=0.722$ for the behavioral component; $\alpha=0.809$ emotional; $\alpha=0.833$ cognitive; and $\alpha=0.863$ total.

\section{Ethical procedures}

The Project was submitted and approved by the University's Institutional Review Board. The sample analyzed in this study was drawn by convenience; the first author contacted schools offering classes to $6^{\text {th }}$ to $9^{\text {th }}$ graders to describe the project and extend invitation for participation in the research. Upon the selection of the four schools and their respective authorizations, the researcher extended an invitation to students, describing the goals and the research process, and highlighting the voluntary nature of participation. 
Informed Consent Forms were handed out to parents and caretakers, and to students, who were free to accept or decline participation. Students only participated if their parents had signed the consent form and simultaneously demonstrated interest in participating. Thus, a total of 907 pairs of informed consent forms were distributed in the four participating schools, each pair for both parents and students. Of these forms, $58.86 \%$ were returned: $46.90 \%$ of students accepted and obtained parental consent and $11.90 \%$ of students refused and/or did not obtain parental consent for participation.

\section{Data collection}

The instruments were applied collectively by the first author, during school hours, and at the schools. During the application, students filled out the instruments regarding bullying involvement, teacher-student relationship, and school engagement, for approximately 40 minutes.

\section{Data analysis}

The variables from the study have a normal distribution, considering the values of symmetry $(S k<|3|)$ and kurtosis $(K u<|10|)$ denoted by Kline (2010). A Confirmatory Factor Analysis was conducted using the Weighted Least Squares Mean and Variance-adjusted (WLSMV) estimation method and polychoric correlation matrices as well as Cronbach's Alpha Coefficient to verify indicators of validity evidence, based on the internal structure and accuracy of the measurement instruments of each variable of interest in the present population sample (the results are presented in the description of the respective instruments). Subsequently, Pearson's bivariate correlation analysis was performed between the variables of interest. Lastly, a Path Analysis was performed to test the proposed explanatory model of school engagement, while simultaneously considering the influence of bullying victimization, bullying perpetration, and teacher- student relationships. For the analysis, Mplus, SPSS, and AMOS software systems were employed.

\section{Results}

Stemming from the analysis of bivariate correlations between the present study's variables of interest, a positive correlation between bullying perpetration and victimization $(r=0.53, p<0.01)$ was noted. Additionally, bullying victimization was negatively associated to teacher-student relationship and school engagement $(r=-0.26$ and $r=-0.26$, respectively; $p<0.01$ ). Furthermore, bullying perpetration was also negatively associated to teacher-student relationship and school engagement $(r=-0.30$ and $r=-0.39$, respectively; $p<0.01)$. Lastly, teacher-student relationships were positively correlated to student school engagement $(r=0.49, p<0.01)$.

An explanatory model of school engagement was tested, based on the literature and correlations found in this study, considering the simultaneous influence of bullying victimization, bullying perpetration, and teacher-student relationships (Figure 1). As the model was shown to be fully saturated, it yields itself as an optimal fit for the data. Thus, the model's suitability indexes were not reported.

The adjusted model accounts for $32 \%$ of the total variance of school engagement. All trajectories were found to be statistically significant, with the exception of the direct effect of bullying victimization on school engagement $(\beta=-0.03$, $p=0.578$ ). Bullying victimization and perpetration are correlated $(r=0.55)$. Additionally, bullying perpetration has a direct negative effect on school engagement ( $\beta=-0.24)$ and in teacher-student relationships $(\beta=-0.25)$, in addition of having an indirect negative effect on school engagement, mediated by teacher-student relationships $(\beta=-0.11)$. Furthermore, bullying victimization has a direct negative effect on teacher-student relationships $(\beta=-0.13)$ and an indirect effect on school engagement mediated by teacher-student relationship ( $\beta=-0.05$ ). Lastly, teacher-student relationships play a direct positive effect on school engagement ( $\beta=0.42$ ). 


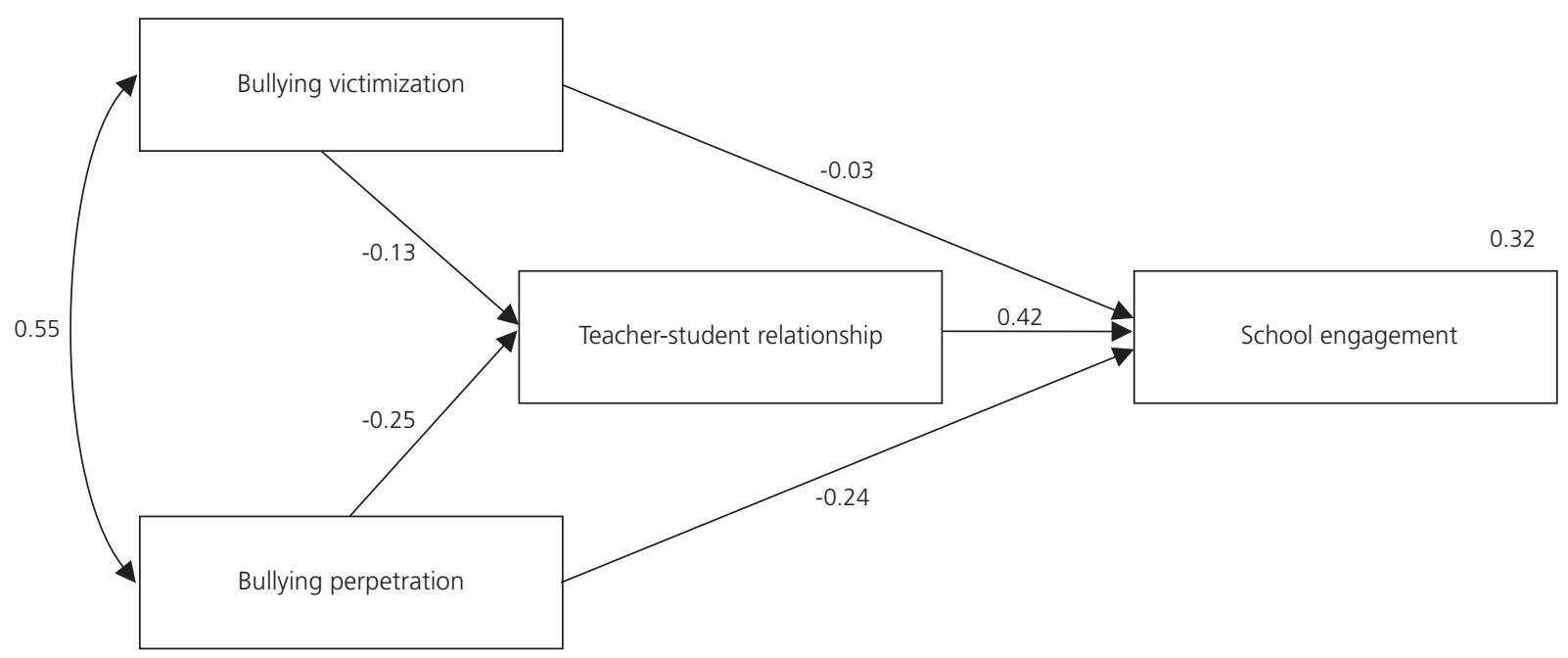

Figure 1. Explanatory model for school engagement.

\section{Discussion}

The goal of this study was to investigate the simultaneous influence of bullying involvement and teacher-student relationship on students' school engagement, through the analysis of an explanatory model. In this respect, the importance of how factors that are present in the school environment may impact school engagement was emphasized, as this understanding would help with the planning of interventions regarding such factors, increasing the probability of academic and social achievement by students.

The correlation analysis of variables performed in this study corroborates the literature findings (Cunha, 2012; Valle et al., 2015), indicating important associations between bullying victimization, bullying perpetration, teacher-student relationships, and school engagement. Thus, the model tested in the study is supported by theoretical and empirical evidence and it strengthens these data. The tested model indicates that bullying victimization and perpetration are associated, corroborating the findings of Valle et al. (2015) that many students who suffer bullying also practice bullying, which is likely a way of retaliating against vulnerable colleagues because of the aggressions students have suffered themselves, perpetuating the cycle of violence.

Furthermore, it is also shown that bullying involvement impairs student school engagement, resulting in lower levels of attendance, higher levels of indiscipline, impaired sense of belonging, loss of emotional connection to school and interest, and less effort in learning, as pointed by lyer et al. (2010) and Mehta et al. (2013). This negative effect may occur because bullying becomes a stressful event for students who are involved, making it difficult to adapt to school demands and social insertion amongst peers (lyer et al., 2010; Mehta et al., 2013).

Therefore it is hypothesized that bullying perpetration is a behavior that competes with other more adequate modalities of behavior, such as prosocial behaviors, paying attention to classes, and having motivation to study, which impairs student school engagement, as victimizing peers could be reinforced by a sensation of power or dominance. In contrast, the direct negative effect of bullying victimization on school engagement was not found to be significant. This is an interesting finding, which was also obtained by Valle et al. (2015), and it could be explained by the fact that victimization may generate negative emotional and psychological consequences, such as anxiety and depression, which in turn impair students' school engagement. Thus, the negative effect of bullying victimization on students' school engagement would be mediated by such variables (Totura, Karver, \& Gesten, 2014; valle et al., 2015). 
Additionally, the quality of teacher-student relationship contributes significantly and in a direct manner to students' school engagement. Therefore a positive relationship with teachers translates into higher levels of school engagement, while a conflicting relationship translates into lower levels of school engagement, a finding that finds support in the literature (Archambault et al., 2013; Portilla et al., 2014; Roorda et al., 2011). In this regard, the contribution that relationships with teachers bear on school engagement could occur due to the fact that positive relationships promote the necessary confidence and autonomy, so that students may explore the environment, getting involved in activities, while negative relationships generate feelings of insecurity (Archambault et al., 2013; Roorda et al., 2011). In addition, it is important to highlight that the study by Valle et al. (2015) found similar results whilst considering staff victimization. Therefore, these results indicate that a positive or a negative relationship with adults within the school environment may have similar impact on student school engagement.

Bullying victimization and perpetration also have direct negative effects on teacher-student relationship, indicating that students involved in bullying have lesser quality relationships with teachers. The authors of this study hypothesize that students who are victims of bullying may be seen as passive, submissive, or less capable, failing, thus, to attract attention to their behavior, in addition to feeling unprotected by teachers during difficult situations. Bullying perpetrators, in turn, may have a conflicting relationship with teachers due to their aggressiveness, which in itself would be a cause of unhealthy interpersonal relationships, in addition to the potential to generate a negative bias towards any of their behaviors, including those within the academic realm.

In light of this, Lamas et al. (2013) point out that often teachers do not assist victims or intervene in bullying cases due to insufficient training, as there is a lack of knowledge on how to deal with the phenomenon. However, as teachers are responsible for students in the school environment as well as for their academic upbringing, they should be considered to be the primary source of student support.

Lastly, teacher-student relationship may mediate the relation between bullying involvement and school engagement. Thus, relationships with teachers may mitigate the negative effects of bullying. Therefore, students who experience positive teacher-student relationships present lower levels of impact on school engagement by bullying involvement. These results corroborate the findings in the existing literature that indicate interactions between the relationships of students with teachers and their peers, and the simultaneous influence of the above on school engagement, as seen in the previously cited studies (Cunha, 2012; Valle et al., 2015). In light of this, it is evident that promoting positive social relations between students and their peers, as well as with teachers, is of utmost importance, as these relations may, by themselves or in conjunction, hinder or facilitate school engagement, especially in regards to bullying perpetrators, whose negative effects on social relationships on school engagement are more significant.

\section{Final Considerations}

As a contribution, to understanding school engagement, the model tested in the present study explains about one-third (32\%) of the variance of the phenomenon, indicating the need to research other variables that may be included in the future, addressing individual, family, social, and cultural factors. However, it should be emphasized that the explained school engagement variance percentage stemming from the relationship with peers and teachers was significant. This indicates that such variables are of extreme importance for school engagement, as they were able to account for an expressive part of a phenomenon considered to be multidimensional, and should be further explored in the future.

In spite of its contributions, this study also presents some limitations. Firstly, the data presented herein is not representative and should not be generalized for the Brazilian population, especially 
due to the fact that the participating schools are from a mid-sized city in the state of São Paulo, whose rates of social vulnerability were considered low and very low. In addition, the study was not longitudinal, and thus it does not allow for causal interpretations, in spite of pointing to how bullying involvement and teacher-student relationship may influence school engagement.

Additionally, the influence of experiencing bullying as a bystander on school engagement was not investigated; the focus was set only on repetitive, systematic, and intentional aggressions. Furthermore, only one instrument was used to evaluate each variable of interest and the instruments were answered only by the students, making the data prone to limitations inherent to questionnaires due to participant bias. Therefore, other sources of data collection could be used to reduce bias and obtain more complete data.

At last, although some psychometric analysis were performed in the present study, such as Confirmatory Factor Analysis and Cronbach's Alpha Coefficient, the instruments employed to evaluate teacher-student relationship and school engagement did not have previous validity evidence for the Brazilian context; nor there were other instruments available in the country with such evidence. This indicates that studies in these areas are scarce and that it is necessary to elaborate and validate instruments regarding these constructs in Brazil.

Despite the limitations listed above, due to the importance that school has on student development and due to the fact that school engagement plays a central role in the academic experience, this study makes a pioneering contribution to the advancement of knowledge in this relevant field of study, pointing out variables present within the school which may influence students' engagement, which may help with intervention strategies to improve the school environment and climate. There are few Brazilian and international studies addressing teacher-student relationships and bullying involvement, and its relation to school engagement, stressing the relevance of the present study.

\section{Contributors}

J.E. VALLE contributed to the conception and design, data analysis and interpretation, discussion of results, revision and approval of the final version of the manuscript. A.C. STELKO-PEREIRA and L.C.A. WILLIAMS contributed to the conception and design, revision of the final version of the manuscript. E.M. PEIXOTO contributed with data analysis and interpretation, revision of the final version of the manuscript.

\section{References}

Albuquerque, P. P., Williams, L. C. A., \& D'Affonseca, S. M. (2013). Efeitos tardios do bullying e Transtorno de Estresse Pós-Traumático: uma revisão crítica. Psicologia: Teoria e Pesquisa, 29(1), 91-98. http:// dx.doi.org/10.1590/S0102-37722013000100011

Archambault, I., Pagani, L. S., \& Fitzpatrick, C. (2013). Transactional associations between classroom engagement and relations with teachers from first through fourth grade. Learning and Instruction, 23, 1-9. http://dx.doi.org/10.1016/j.learninstruc.2012.09.003

Berger, K. S. (2007). Update on bullying at school: Science forgotten? Developmental Review, 27(1), 90-126. http://dx.doi.org/10.1016/j.dr.2006.08.002

Brito, C. C., \& Oliveira, M. T. (2013). Bullying e autoestima em adolescentes de escolas públicas. Jornal de Pediatria, 89(6), 601-607. http://dx.doi.org/10.1016/j. jped.2013.04.001

Cunha, J. M. (2012). O papel moderador de docentes na associação entre violência escolar e ajustamento acadêmico (Dissertação de mestrado não-publicada). Universidade Federal do Paraná, Curitiba.

Fredricks, J. A., Blumenfeld, P. C., \& Paris, A. H. (2004). School engagement: Potential of the concept, state of the evidence. Review of Educational Research, 74(1), 59-109. http://dx.doi.org/10.310 2/00346543074001059

Fredricks, J. A., Blumenfeld, P. C., Friedel, J., \& Paris, A. (2005). School engagement. In K. A. Moore, \& L. Lippman (Eds.), What do children need to flourish? Conceptualizing and measuring indicators of positive development (pp.305-321). New York: Kluwer Academic/Plenum Press.

Fundação do Sistema Estadual de Análise de Dados [SEAD]. (2010). Índice Paulista de Vulnerabilidade Social (IPVS): Versão 2010. Recuperado em dezembro 22, 2016, de http://indices-ilp.al.sp.gov.br/view/index. php?prodCod=2

Gladden, R. M., Vivolo-Kantor, A. M., Hamburger, M. E., \& Lumpkin, C. D. (2014). Bullying surveillance among youths: Uniform definitions for public health and recommended data elements. Atlanta: Centers for Disease Control and Prevention. 
Hamre, B. K., Pianta, R. C., Downer, J. T., \& Mashburn, S. J. (2008). Teachers' perceptions of conflict with young students: Looking beyond problem behaviors. Social Development, 17(1), 115-136. http://dx.doi. org/10.1111/j.1467-9507.2007.00418.x

lyer, R. V., Kochenderfer-Ladd, B., Eisenberg, N., \& Thompson, M. (2010). Peer victimization and effortful control: Relations to school engagement and academic achievement. Merril-Palmer Quarterly, 56(3), 361-387. http://dx.doi.org/10.1353/mpq.0.0058

Kline, R. B. (2010). Principles and practice of structural equation modeling (3rd ed.). New York: Guilford Press.

Lamas, K. C. A., Freitas, E. R., \& Barbosa, A. J. G. (2013). Bullying e relação professor-aluno: percepções de estudantes do Ensino Fundamental. Psico, 44(2), 263-272.

Li, Y., \& Lerner, R. M. (2013). Interrelations of behavioral, emotional, and cognitive school engagement in High School students. Journal of Youth Adolescence, 42(1), 20-32. http://dx.doi.org/10.1007/s10964-012-9857-5

Malta, D. C., Porto, D. L., Crespo, C. D., Silva, M. M. A., Andrade, S .S. C., Mello, F. C. M., ... Silva, M. A. I. (2014). Bullying em escolares brasileiros: análise da Pesquisa Nacional de Saúde do Escolar (PeNSE 2012). Revista Brasileira de Epidemiologia, 17(1), 92-105. http://dx.doi.org/10.1590/1809-4503201400050011

Mehta, S. B., Cornell, D., Fan, X., \& Gregory, A. (2013). Bullying climate and school engagement in ninthgrade students. Journal of School Health, 83(1), 45-52. http://dx.doi.org/10.1111/j.1746-1561.2012.00746.x

Olweus, D. (1993). Bullying at school: What we know and what we can do. Cambridge: Backwell.

Organisation for Economic Co-operation and Development (2013). PISA 2012 Results: Ready to learn: Students' engagement, drive and self-beliefs (Vol. 3). Pisa: OECD Publishing. http://dx.doi.org/10. 1787/9789264201170-en

Orpinas, P., \& Horne, A. M. (2006). Bullies and victims: A challenge for schools. In J. R. Lutzker (Ed.), Preventing violence: Research and evidence-based intervention strategies (pp.147-165). Washington, DC: American Psychological Association.
Penrose, R. (2009). Teacher-student relationship (Unpublished master's thesis). California State University, Sacramento, United States.

Portilla, X. A., Ballard, P. J., Adler, N. E., Boyce, W. T., \& Obradovic, J. (2014). An integrative view of school functioning: Transactions between self-regulation, school engagement, and teacher-child relationship quality. Child Development, 85(5), 1915-1931. http:// dx.doi.org/10.1111/cdev.12259

Rech, R. R., Halpern, R., Tedesco, A., \& Santos, D. F. (2013). Prevalence and characteristics of victims and perpetrators of bullying. Jornal de Pediatria, 89(2), 164-170. http://dx.doi.org/10.1016/j.jped.2013.03.006

Roorda, D. L., Koomen, H. M. Y., Spilt, J. L., \& Oort, F. J. (2011). The influence of affective teacher-student relationships on students' school engagement and achievement: A meta-analytic approach. Review of Educational Research, 81(4), 493-529. http://dx.doi. org/10.3102/0034654311421793

Stelko-Pereira, A. C., Williams, L. C. A., \& Freitas, L. C. (2010). Validade e consistência interna do questionário de investigação de prevalência de violência escolar: versão estudantes. Avaliação Psicológica, 9(3), 403-411.

Totura, C. M. W., Karver, M. S., \& Gesten, E. L. (2014). Psychological distress and student engagement as mediators of the relationship between peer victimization and achievement in Middle School youth. Journal of Youth Adolescence, 43(1), 40-52. http:// dx.doi.org/10.1007/s10964-013-9918-4

Valle, J. E., Stelko-Pereira, A. C., Sá, L. G. C., \& Williams, L. C. A. (2015). Bullying, vitimização por funcionários e depressão: relações com o engajamento emocional escolar. Psicologia Escolar e Educacional, 19(3), 463-473. http://dx.doi.org/10.1590/21753539/2015/0193872

Williams, L. C. A., \& Stelko-Pereira, A. C. (2013). Por fora bela viola: pesquisa e intervenção sobre cyberbullying. In C. N. Abreu, E. Eisenstein, \& S. G. B. Estefenon (Orgs.), Vivendo esse mundo digital: impactos na saúde, na educação e nos comportamentos sociais (pp.49-59). Porto Alegre: Artmed.

Received: August 31, 2017

Approved: December 5, 2017 